\title{
HUBUNGAN PENGETAHUAN DAN PROSEDUR KERJA SEBAGAI \\ UPAYA PENCEGAHAN PENYAKIT AKIBAT KERJA PADA \\ PERAWAT DI RUMAH SAKIT
}

\author{
Januarizkah Napitu \\ januarizkahnapitu@gmail.com
}

\section{LATAR BELAKANG}

Rumah sakit (RS) merupakan tempat kerja yang berpotensi tinggi terhadap terjadinya kecelakaan kerja. Adanya bahan mudah terbakar, gas medis, radiasi pengion dan bahan kimia membutuhkan perhatian serius terhadap keselamatan pasien, staf dan umum (Sarastuti, 2016). Kecelakaan adalah kejadian tidak terduga yang disebabkan oleh tindakan tidak aman dan kondisi tidak aman (Heinrich, 1930).

Tenaga kesehatan yang sering berkontak langsung dengan pasien adalah perawat. Perawat mempunyai risiko yang tinggi untuk menerima pajanan penyakit akibat adanya infeksi yang dapat mengancam keselamatannya saat berkerja. . Perawat juga bertanggung jawab menjaga keselamatan klien dirumah sakit melalui pencegahan kecelakaan, cidera, trauma, dan melalui penyebaran infeksi nosokomial.

Kecelakaan kerja pada perawat dianggap sebagai suatu masalah serius karena mengancam kesehatan dan kesejahteraan pasien dan petugas kesehatan secara global (Maria, 2015). Kecelakaan tersebut yang pada akhirnya dapat mempengaruhi produktivitas kerja perawat. Produktivitas kerja yang rendah pada akhirnya berdampak terhadap pelayanan kesehatan yang diberikan oleh rumah sakit. Kecelakaan kerja pada perawat ini menimbulkan kerugian bagi perawat itu sendiri maupun pihak rumah sakit

Aktifitas perawat yang tinggi dan cepat, hal ini menyebabkan perawat kurang memperhatikan tehnik septik dalam melakukan tindakan keperawatan (Potter, 2005). Upaya untuk mengendalikan, meminimalisasi dan bila mungkin meniadakannya, oleh karena itu K3RS perlu dikelola dengan baik. Sistem Manajemen Kesehatan dan Keselamatan Kerja merupakan sesuatu yang baru dan menjadi sasaran penilaian akreditasi rumah sakit. Selain itu SMK3 merupakan faktor yang secara tidak langsung berhubungan dengan pasien, tetapi 
memegang peran penting dalam pelayanan rumah sakit. negara berkembang seperti Indonesia masih sangat tinggi.

Hasil laporan National Safety Council tahun 1988 menunjukkan bahwa terjadinya kecelakaan kerja di rumah sakit 41\% lebih besar dari pekerja industri lainnya. Kasus yang sering terjadi adalah tertusuk jarum, terkilir, sakit pinggang, tergores, luka bakar dan penyakit infeksi lainnya. Upaya penerapan K3 di rumah sakit menyangkut tenaga kerja, cara/metode kerja, alat kerja, proses kerja, dan lingkungan kerja yangmeliputi peningkatan, pencegahan, pengobatan,dan pemulihan. Mengingat bahwa perawat merupakan tenaga kesehatan yang sering berkontak langsung dengan pasien, Saya bertujuan untuk mencari tahu hubungan pengetahuan dan prosedur kerja perawat sebagai upaya pencegahan penyakit akibat kerja pada perawat di Rumah Sakit.

\section{METODE}

Metode yang saya gunakan dalam membuat artikel ini disebut literasi. Saya membaca beberapa informasi dari berbagai sumber referensi berupa buku, dan jurnal. Melalui metode inilah saya memahami dan mengidentifikasi hubungan pengetahuan dan prosedur kerja sebagai upaya pencegahan penyakit akibat kerja pada perawat dirumah sakit.

\section{HASIL}

Rumah Sakit merupakan tempat yang sangat kompleks, terdapat ratusan macam obat, ratusan test dan prosedur, banyak terdapat alat dan teknologi, bermacam profesi dan non profesi yang memberikan pelayanan pasien selama 24 jam secara terus-menerus, di mana keberagaman dan kerumitan pelayanan tersebut apabila tidak dikelola dengan baikdapat terjadi Insiden Keselamatan Pasien bisa berupa Kejadian Tidak Diharapkan (KTD/Adverse event) (Depkes 2008). Rumah sakit sebagai industri jasa merupakan sebuah industri yang mempunyai beragam persoalan tenaga kerja yang rumit dengan berbagai risiko terkena penyakit akibat kerja bahkan kecelakan akibat kerja sesuai jenis pekerjaannya, sehingga berkewajiban menerapkan upaya Keselamatan dan Kesehatan Kerja Rumah Sakit . (Toding, 2016). 
Selain dituntut mempu memberikan pelayanan dan pengobatan yang bermutu, Rumah Sakit juga dituntut harus melaksanakan dan mengembangkan program Kesehatan dan Keselamatan Kerja di Rumah Sakit (K3RS) seperti yang tercantum dalam buku Standar Pelayanan Rumah Sakit dan terdapat dalam instrumen akreditasi Rumah Sakit. Rumah Sakit harus menjamin kesehatan dan keselamatan baik terhadap pasien, penyedia layanan atau pekerja maupun masyarakat sekitar dari berbagai potensi bahaya di Rumah Sakit. Oleh karena itu, Rumah Sakit dituntut untuk melaksanakan Upaya Kesehatan dan Keselamatan Kerja yang dilaksanakan secara terintegrasi dan menyeluruh sehingga risiko terjadinya Penyakit Akibat Kerja (PAK) dan Kecelakaan Akibat Kerja (KAK) di Rumah Sakit dapat dihindari. Sasaran utama K3RS adalah tenaga medis, tenaga non medis, pasien, pengunjung / pengantar pasien, serta masyarakat sekitar Rumah Sakit.

Perawat adalah seseorang yang telah menyelesaikan program pendidikan keperawatan baik didalam maupun luar negeri yang diakui oleh Pemerintah Republik Indonesia. Kini, pengertian perawat merujuk pada posisinya sebagai bagian dari tenaga kesehatan yang memberikan pelayanan kepada masyarakat secara profesional. Kecelakaan kerja pada perawat dianggap sebagai suatu masalah serius karena mengancam kesehatan dan kesejahteraan pasien dan petugas kesehatan secara global (Maria, 2015). Kecelakaan tersebut yang pada akhirnya dapat mempengaruhi produktivitas kerja perawat. Produktivitas kerja yang rendah pada akhirnya berdampak terhadap pelayanan kesehatan yang diberikan oleh rumah sakit. Kemampuan perawat untuk mencegah transmisi infeksi dirumah sakit dan upaya pencegahan adalah tingkat pertama dalam pemberian pelayanan bermutu.

Berdasarkan keterangan salah satu jurnal yang saya jadikan sebagai referensi, yang berjudul, "Hubungan pengetahuan dengan upaya penerapan K3 pada perawat" yang ditulis oleh Nida Dini Hanifa, Titik Respati, dan Yuli Susanti yang menyimpulkan Berdasarkan penelitian ini dapat disimpulkan terdapat hubungan bermakna antara tingkat pengetahuan dengan upaya penerapan K3 pada responden di salah satu rumah sakit umum daerah Kabupaten Bandung. Berdasarkan keterangan salah satu jurnal yang saya jadikan sebagai referensi, yang berjudul "Hubungan antara pengawasan, prosedur kerja dan kondisi fisik dengan terjadinya kecelakaan kerja pada perawat di ruang rawat inap rumah sakit permata bunda Medan tahun 2017” yang ditulis oleh Nur Azizah, Setiawan dan Gerry Silaban yang menyimpulkan bahwa Ada hubungan yang signifikan antara prosedur kerja dengan kecelakaan kerja perawat di ruang rawat inap Rumah Sakit. 


\section{PEMBAHASAN}

\section{A. Kecelakaan Kerja dalam Perawat di Rumah Sakit}

Kesehatan dan Keselamatan Kerja (K3) merupakan suatu upaya perlindungan kepada tenaga kerja dan orang lain yang memasuki tempat kerja terhadap bahaya dari akibat kecelakaan kerja (Tarwaka, 2008). Tujuan K3 adalah mencegah, megurangi, bahkan menihilkan risiko penyakit dan kecelakaan akibat kerja (KAK) serta meningkatkan derajat kesehatan para perawat sehingga produktivitas kerja meningkat.

Menurut Undang-undang No. 44 Tahun 2009 Rumah Sakit adalah institusi pelayanan kesehatan bagi masyarakat dengan karakteristik tersendiri yang dipengaruhi oleh perkembangan ilmu pengetahuan kesehatan, kemajuan teknologi, dan kehidupan sosial ekonomi masyarakat yang harus tetap mampu meningkatkan pelayanan yang lebih bermutu dan terjangkau oleh masyarakat agar terwujud derajat kesehatan yang setinggi-tingginya.

Perawat adalah seseorang yang telah menyelesaikan program pendidikan keperawatan baik didalam maupun luar negeri yang diakui oleh Pemerintah Republik Indonesia sesuai dengan peraturan perundang-undangan (Undang-Undang RI Nomor 38, 2014). Kini, pengertian perawat merujuk pada posisinya sebagai bagian dari tenaga kesehatan yang memberikan pelayanan kepada masyarakat secara profesional.

Kecelakaan kerja pada perawat dianggap sebagai suatu masalah serius karena mengancam kesehatan dan kesejahteraan pasien dan petugas kesehatan secara global (Maria, 2015). Kecelakaan tersebut yang pada akhirnya dapat mempengaruhi produktivitas kerja perawat. Produktivitas kerja yang rendah pada akhirnya berdampak terhadap pelayanan kesehatan yang diberikan oleh rumah sakit. Kemampuan perawat untuk mencegah transmisi infeksi dirumah sakit dan upaya pencegahan adalah tingkat pertama dalam pemberian pelayanan bermutu.

\section{B. Resiko kerja pada perawat}

Potensi bahaya dan risiko pada perawat di rumah sakit perawat berisiko terhadap bahaya-bahaya potensial di Rumah Sakit yang dapat menyebabkan penyakit akibat kerja maupun kecelakaan kerja disebabkan oleh faktor biologi, faktor kimia, faktor ergonom, faktor fisik dan faktor psikososial yang dapat mengakibatkan penyakit dan kecelakaan akibat kerja (Permenkes Nomor 66 Tahun 2016).

Prinsip Bahaya untuk perawat antara lain: (OSHA, 2009)

1. Patogen melalui darah

2. Bahan kimia berbahaya : (misalnya, etilen oksid, obat tumpah, bahan karsigonen, asap berbahaya, dan cairan mudah terbakar). 


\section{Slips/jatuh.}

4. Alergi lateks : (misalnya, reaksi terhaap sarung tangan terbuat dari lateks alam dan atau bahan yang digunakan untuk membuat sarung tangan.

5. Bahaya peralatan : misalnya kejutan listrik, defribilator, tertusuk jarum.

6. Stess kerja :

a. Faktor-faktor : shift kerja, Jam kerja yang panjang, kelelahan, situasi emotional yang kuat (penderitaan dan kematian), keselamatan pasien (kesalahan pengobatan). Risiko yang dihadapi : penyakit jantung, gangguan psikologis, cidera di tempat kerja dan masalah kesehatan lainnya).

b. Peringatan dini : sakit kepala, gangguan tidur, kesulitan konsentrasi, ketidak puasan kerja dan semangat kerja yang turun.

\section{Infeksi Methicilin Resistant Staphylococcus.}

8. Workplace violence: serangan fisik luar (memaki,ancaman).

9. Terorisme : misalnya menerima korban dari sebuah insiden teroris yang tidak diketahui identitasnya.

10. Bahaya fisik : misalnya flying obyects, cid

\section{Definisi pengetahuan}

Pengetahuan yakni hasil tahu seseorang dan terjadi setelah orang melakukan pengamatan dan pengindraan terhadap suatu objek tertentu. Pengetahuan merupakan suatu hal yang sangat penting dalam membentuk tindakan perilaku seseorang. Pengetahuan merupakan hasil dari tahu dan ini terjadi setelah orang melakukan penginderaan terhadap suatu objek tertentu. Penginderaan terjadi melalui pancaindra manusia yakni indra penglihatan, pendengaran, penciuman, rasa dan raba. Sebagian besar pengetahuan diperoleh melalui mata dan telinga (Notoatmodjo, 2014).

Pencegahan kecelakaan berdasarkan pengetahuan tentang penyebab kecelakaan. Sebab-sebab kecelakaan pada suatu perusahaan diketahui dengan mengadakan analisis setiap kecelakaan yang terjadi. Selain analisis mengenai penyebab terjadinya suatu peristiwa kecelakaan, untuk pencegahan kecelakaan kerja sangat penting artinya dilakukan identifikasi bahaya yang terdapat dan mungkin menimbulkan insiden kecelakaan di perusahaan serta mengases. Pencegahan kecelakaan terhadap faktor manusia meliputi peraturan kerja, mempertimbangkan batas kemampuan dan ketrampilan pekerja, meniadakan halhal yang mengurangi konsentrasi kerja, menegakkan disiplin kerja, menghindari perbuatan yang mendatangkan kecelakaan serta menghilangkan adanya ketidak 
cocokan fisik dan mental

\section{Definisi Prosedur kerja}

Prosedur kerja merupakan rangkaian langkah yang dilaksanakan untuk menyelesaikan kegiatan atau aktivitas, sehingga dapat tercapai tujuan yang diharapkan secara efektif dan efisien serta dapat dengan mudah menyelesaikan suatu masalah yang terperinci menurut waktu yang telah ditetapkan. Perawat juga memiliki prosedur kerja yang sudah ditetapkan dimana prosedur tersebut digunakan untuk melindungi perawat dan juga melindungi pasien.

\section{E. Hubungan pengetahuan perawat sebagai upaya pencegahan penyakit}

Berdasarkan keterangan salah satu jurnal yang saya jadikan sebagai referensi, yang berjudul, "Hubungan pengetahuan dengan upaya penerapan K3 pada perawat" yang ditulis oleh Nida Dini Hanifa, Titik Respati, dan Yuli Susanti yang berisikan bahwa Faktor yang dapat memengaruhi tingkat pengetahuan $\mathrm{K} 3$ pada penelitian ini adalah pendidikan, usia, dan lama kerja.4,7,22 Pendidikan terakhir responden sebagian besar adalah D-III sebanyak 29 orang (94\%). Hal ini menunjukkan bahwa pendidikan yang tinggi dapat meningkatkan pengetahuan seseorang. Oleh sebab itu, semakin tinggi pendidikan seseorang, pengetahuan yang dimilikinya akan semakin baik. Pengetahuan yang cukup pada hasil penelitian ini juga dipengaruhi oleh lama kerja seseorang. Hal ini sesuai dengan penelitian terdahulu dimana pekerja yang memiliki masa kerja lebih dari satu tahun cenderung lebih rendah dalam mengalami kecelakaan kerja.

Lama kerja kurang dari enam bulan memiliki risiko lebih tinggi untuk mengalami kecelakaan kerja, Pengetahuan dapat diperoleh melalui pengalaman, baik pengalaman sendiri ataupun pengalaman orang lain. Sumber pengetahuan K3 tidak hanya seseorang dapatkan dari institusi saja tetapi bisa juga didapatkan sebelum seseorang Penerapan K3 oleh responden tergolong baik. Hal ini berhubungan dengan pengetahuan K3 yang cukup, sikap individu yang sudah baik, dan juga informasi K3 yang mereka dapatkan sendiri. Meskipun pengetahuan $\mathrm{K} 3$ yang dimiliki responden masih tergolong cukup, tetapi tiga alasan pokok lainnya mampu menunjang untuk menerapkan K3 dengan baik hingga dihasilkannya penerapan $\mathrm{K} 3$ yang baik pada responden.

Berdasar atas hasil penelitian didapatkan tingkat pengetahuan K3 yang cukup (61\%) sedangkan upaya penerapan K3 yang baik (68\%). Hasil penelitian ini sesuai dengan Penelitian yang dilakukan oleh Tumalun dkk. di RS Robert Wolter Mongisidi, Manado. Populasi dalam penelitian tersebut adalah semua perawat rumah sakit bagian unit ICU, IGD, 
Rawat Inap danPoli berjumlah 58 perawat serta didapatkan hubungan antara pengetahuan tentang K3RS dan penerapan praktik K3RS, begitu pula dengan sikap terhadap K3RS dengan penerapan praktik K3RS pada perawat RS tersebut. Hasil penelitian Dito dan Hariyono di RS Condong Catur, Sleman menunjukkan tidak terdapatnya hubungan antara pengetahuan dengan penerapan $\mathrm{K} 3$.

Hal ini disebabkan karena beberapa faktor salah satunya dikarenakan pengetahuan paramedis terhadap pencegahan infeksi nosokomial kurang baik. Hasil yang bersebrangan ini dapat disebabkan karena cara pengumpulan informasi yang berbeda. Penelitian ini menunjukkan bahwa K3 pada responden telah berjalan dengan baik sehingga terbukti dapat menekan angka kecelakaan kerja yang terjadi.9-19 Jika dibandingkan dengan penelitian Salawati dkk.31 pada 22 perawat ICU RSUD dr. Zainoel Abidin, Banda Aceh sebanyak 10 orang memiliki pengetahuan yang baik serta tindakan $\mathrm{K} 3$ yang baik pula $(76,9 \%)$, begitupun perawat yang memiliki pengetahuan yang kurang cenderung melakukan tindakan K3 yang kurang baik (77,8\%). Hal ini menunjukkan bahwa terdapat hubungan yang signifikan antara pengetahuan dan upaya penerapan K3.

\section{F. Hubungan prosedur kerja perawat sebagai upaya pencegahan penyakit}

Berdasarkan keterangan salah satu jurnal yang saya jadikan sebagai referensi, yang berjudul "Hubungan antara pengawasan, prosedur kerja dan kondisi fisik dengan terjadinya kecelakaan kerja pada perawat di ruang rawat inap rumah sakit permata bunda Medan tahun 2017" yang ditulis oleh Nur Azizah, Setiawan dan Gerry Silaban yang berisikan bahwa Penilaian hubungan antara prosedur kerja dengan kecelakaan perawat di ruang rawat inap Rumah Sakit Permata Bunda menunjukkan nilai $\mathrm{p}=0,010<0,05$ yang artinya ada hubungan yang signifikan antara prosedur kerja dengan kecelakaan perawat di ruang rawat inap Rumah Sakit Permata Bunda.

Berdasarkan hasil penjabaran wawancara dan hasil observasi atas prosedur kerja, terhadap kepala ruangan bahwa hampir semua perawat yang bertugas selalu melakukan pekerjaan atau tindakan sesuai dengan standar yang diterapkan. Beberapa perawat yang terlupa atau tidak sesuai dengan prosedur dalam melakukan tindakan mungkin disebabkan karena buru-buru atau sedang dalam kondisi yang tidak sehat. Kepala perawat menyatakan bahwa seorang perawat harus memiliki sikap yang baik seperti mengikuti prosedur kerja dan harus peduli terhadap bahaya yang ada dirumah sakit, karena perawat tidak hanya bertanggung jawab terhadap keselamatannya sendiri tetapi yang terutama itu harus memperhatikan keselamatan pasien juga karena jika mereka bersikap yang buruk hal ini 
menyangkut mutu pelayanan rumah sakit juga. Tetapi masih adanya perawat yang bersikap kurang sesuai, seperti masih ada perawat yang tidak memakai sarung tangan saat menyuntik yang mungkin karena agar lebih gampang pada saat akan melakukan tindakan. beberapa dari perawat masih ada yang belum memiliki kesadaran untuk menerapkan prosedur kerja dalam melakukan pekerjaannya karena belum ada sanksi yang tegas, hanya berupa teguran saja, ada juga pekerja merasa terbebani dengan beberapa prosedur kerja, dan ada juga menyatakan prosedur kerja membuat pekerjaan merela lebih lambat. Perilaku tidak aman perawat saat bekerja tanpa menggunakan alat peindung diri sesuai dengan standart dapat mengakbatkan kecelakaan kerja dan menimbulkan penyakit akibat kerja.

Peningkatan kepatuhan perawat dalam melaksakan prosedur kerja dapat dilakukan dengan cara meningkatan kesadaran perawat untuk bertindak aman dalam upaya meningkatkan keselamatan dan kesehatan saat bekerja. Kesadaran perawat dapat ditumbuhkan dengan cara pelatihan-pelatihan guna meningkatkan pengetahuan perawat mengenai keselamatan dan kesehatan kerja dan juga pengetahuan mengenai bahaya kerja pada perawat sehingga perawat secara mandiri dapat berperilaku aman saat bekerja.

\section{PENUTUP}

Potensi bahaya dan risiko pada perawat di rumah sakit perawat berisiko terhadap bahaya-bahaya potensial di Rumah Sakit yang dapat menyebabkan penyakit akibat kerja maupun kecelakaan kerja disebabkan oleh faktor biologi, faktor kimia, faktor ergonom, faktor fisik dan faktor psikososial yang dapat mengakibatkan penyakit dan kecelakaan akibat kerja (Permenkes Nomor 66 Tahun 2016). Berdasarkan keterangan salah satu jurnal yang saya jadikan sebagai referensi dapat disimpulkan terdapat hubungan bermakna antara tingkat pengetahuan dengan upaya penerapan K3 pada responden di salah satu rumah sakit umum daerah Kabupaten Bandung dan ada hubungan yang signifikan antara prosedur kerja dengan kecelakaan kerja perawat di ruang rawat inap Rumah Sakit.

\section{DAFTAR PUSTAKA}

1) Azizah, Nur., Setiawan., \& Silaban, Gerry., (2019). Hubungan Antara Pengawasan, Prosedur Kerja Dan Kondisi Fisik Dengan Terjadinya Kecelakaan Kerja Pada Perawat Di 
Ruang Rawat Inap Rumah Sakitpermata Bunda Medan Tahun 2017. Jurnal JUMANTIK Vol. 3 No. 2

2) Azzahri, Lira Mufti., \& Ikhwan Khairul. (2019). Hubungan Pengetahuan Tentang Penggunaan Alat Pelindung Diri (Apd) Dengan Kepatuhan Penggunaan Apd Pada Perawat Di Puskesmas Kuok PREPOTIF Jurnal Kesehatan Masyarakat Volume 3, Nomor 1

3) Hanifa, Nida Dini., Respati Titik., \& Susanti, Yuli. (2017). Hubungan Pengetahuan dengan Upaya Penerapan K3 pada Perawat. Meeting on Global Medicine \& Health (BaMGMH), Vol. 1 No. 1

4) I, Silvia Maria P., Wiyono, Joko., \& Candrawati, Erlisa. (2016). Kejadian Kecelakaan Kerja Perawat Berdasarkan Tindakan Tidak Aman. Jurnal Care Vol. 3, No. 2

5) Iskandar, E. (2017). Tata Kelola dan Kepatuhan Penerapan Standar Patient Safety Penyakit Stroke di Rumah Sakit Dr. Kanujoso Djatiwibowo Tahun 2015. Jurnal ARSI .3 (3):1-12.

6) Mantiri, Ezra Zimri Ruben Abiam., Pinontoan Odi R., \& Mandley, Sylvia. (2020). Faktor Psikologi Dan Perilaku Dengan Penerapan Manajemen Keselamatan Dan Kesehatan Kerja Rumah Sakit. Indonesian Journal of Public Health and Community Medicine Vol 1 No. 3

7) Octavia, Widiawati Rinjani., Nerawati, A.T. Diana., \& Sari, Ernita., (2018). Penerapan Pelayanan Kesehatan Dan Keselamatan Kerja Pada Perawat IGD Rumah Sakit Umum Dr. Wahidin Sudiro Husodo Mojokerto Tahun 2017. Gema Kesehatan Lingkungan Vol. 16 No. 1

8) Puspasari, Yunita. (2015). Hubungan Pengetahuan, Sikap Dengan Praktik Perawat Dalam Pencegahan Infeksi Nosokomial Diruang Rawat Inap Rumah Sakit Islam. Kendal Fikkes Jurnal Keperawatan Vol. 8 No. $1: 23-43$

9) Simamora, R. H. (2020). Pelatihan Komunikasi Efektif untuk Meningkatkan Efikasi diri Perawat dalam Pelaksanaan Identifikasi Pasien. Jurnal Ilmiah Kesehatan Masyarakat: Media Komunikasi Komunitas Kesehatan Masyarakat, 12(1), 49-54. 
10) Simamora, R. H. (2011). Role Conflict Of Nurse Relationship With Performance In The Emergency Unit Of Hospitals Rsd Dr. Soebandi Jember. The Malaysian Journal of Nursing, $3(2), 23-32$.

11 ) Suharto., \& Suminar, Ratna. (2016). Hubungan Pengetahuan dan Sikap Perawat Dengan Tindakan Pencegahan Infeksi Di Ruang ICU Rumah Sakit. Jurnal Riset Hesti Medan, Vol. 1, No. 1

12) Tamboto, Christi Debora., Kandou, Grace D., \& Kawatu, Paul A.T. (2016). Analisis penerapan standar pelayanan kesehatan dan keselamatan kerja rumah sakit (K3RS) di RSUP ratatotok buyat ratatotok kabupaten minahasa tenggara. Jurnal fakultas kesehatan masyarakat universitas sam ratulangi, 1(7), 1-10 